\title{
Interactive comment on "Impact of karst areas on runoff generation, lateral flow and interbasin groundwater flow at the storm-event timescale" by Martin Le Mesnil et al.
}

\section{Martin Le Mesnil et al.}

martin.le-mesnil@inra.fr

Received and published: 9 September 2020

We are very grateful for the constructive comments of Anonymous Referee \#2 on the manuscript. We believe that they will help increasing substantially the scientific quality of the manuscript. We agree with most recommendations and we give our responses to all remarks in the attached supplementary file.

Please also note the supplement to this comment: supplement.pdf 
Interactive comment on Hydrol. Earth Syst. Sci. Discuss., https://doi.org/10.5194/hess-2020229, 2020.

Interactive

comment 